
\title{
R Research S Surare \\ Climate Change and Odawa Cultural Plants in Sleeping Bear Dunes National Lake Shore
}

Richard William Stoffle ( $\nabla$ rstoffle@email.arizona.edu )

University of Arizona https://orcid.org/0000-0002-0768-4789

Michaei J. Evans

National Park Service

Christooher Sittler Sittler

UA: The University of Arizona

Desmond L. Berry

: Grand Traverse Band of Ottawa and Chippewa Indians

Kathleen Van Vlack

Living Heritage Research Council

\section{Research Article}

Keywords:

Posted Date: January 11th, 2022

DOl: https://doi.org/10.21203/rs.3.rs-869301/v1

License: (c) (1) This work is licensed under a Creative Commons Attribution 4.0 International License. Read Full License 


\begin{abstract}
Climate change has been observed for hundreds of years by plant specialists of three Odawa Tribes in the Upper Great Lakes along Lake Michigan. Sleeping Bear Dunes National Lakeshore is the focus of two National Park Service-funded studies of Odawa Traditional Ecological Knowledge (TEK) of plants and ecosystems and climate change impacts on these. Data collected during these ethnobotany studies were designed to contribute to a Plant Gathering Agreement between the tribes and the park. This essay provides an analysis of these observations derived from 95 ethnographic interviews conducted by University of Arizona anthropologists. Odawa people recognize in the park 288 plants and five habitats of traditional and contemporary concern. Tribal representatives explained how 115 of these traditional plants and all five habitats are known from multigenerational eyewitness accounts to have been impacted by climate change.
\end{abstract}




\section{INTRODUCTION}

The National Park Service (NPS) and three Odawa Tribes in northern Michigan combined to better understand tribal Traditional Ecological Knowledge (TEK) related to environmental indicators of climate change. To accomplish this goal, tribal representatives participated in information sharing visits at several locations in Sleeping Bear Dunes National Lake Shore (SLBE) (Figure 1, Figure 2).

NPS funded the 2014 study of Odawa perceptions of climate change to be the first climate change study of its kind conducted in the lower 48 states (Stoffle et al. 2015). Earlier, in 1998, the NPS funded a multiple park ethnographic study of Odawa cultural adaptations to the natural environment throughout the western Great Lakes (Stoffle et al. 2001). That study also involved Odawa ecological interviews conducted in SLBE. Findings from the two studies are combined in this analysis.

Study goals were achieved by documenting a total of 288 traditional use plants and five unique habitats that are culturally special to the Odawa people. Of these, 115 plants and all five habitats were perceived through eyewitness accounts by the Odawa representatives to have been impacted by climate change within the past few generations.

A common purpose of the 1998 and 2014 studies was to document Traditional Ecological Knowledge categories of plants and their ecosystems. The gathering of plant data in 2014 was guided by NPS expectations regarding the kinds of Traditional Ecological Knowledge that would be required so a park and a tribe could prepare an ethnobotanical document for establishing a Plant Gathering Agreement under "Gathering of Certain Plants or Plant Parts by Federally Recognized Indian Tribes for Traditional Purposes” rule 36 CFR Part 2 (Code of Federal Regulations, title 32, sec. 2.6. 2016). This purpose was achieved and the study 2014 study was 
referenced as a model "...that NPS and tribal governments can draw upon this research and may conduct further research to ensure that traditional tribal gathering and removal does not have a significant adverse impact..." in the published the Final Rule (Federal Register Vol. 81 No. 133, July 12, 2016: p. 45026).

These two ethnographic studies contributed to developing mutual understandings of how Odawa traditional knowledge potentially can contribute to the park management of plants and ecosystems. As the first formal consultations between the park and the tribes these studies provided a foundation for future consultations. The findings were approved by tribal governments for public use by the NPS in interpretation and management.

\section{BACKGROUND}

Climate change is a global issue. Although all of the world's population will be affected by climate change, people who have long place-based histories, complex environmental coadaptations, and cultural memories of resource changes have a special role in future climate adaptations. Paerregaard's (2020) research on climate change awareness among highland Peruvian communicates concludes that climate change research is a post-normal science that not only must engage a range of scholarly traditions and methods but also listen to the voices of the people who are affected by climate change.

As fluctuations in precipitation and temperatures are combined with more frequent and extreme weather events most ecosystems will be altered (Glassberg 2014). Charles Darwin maintained that while species would be forced to adapt to new situations, the fundamental parameters of ecology would remain the same. Fox (2007: 823-825), however, suggests that the concept of a No-Analog Future best describes ecological conditions where species and natural conditions are reshuffled into novel combinations that were unknown in the past. Thus, while 
some human co-adaptations with the environment may no longer be of use in the future, some adaptations, especially protocols for adapting and the philosophy of co-adaption itself may provide models for future peoples (Stoffle, Arnold, and Van Vlack 2015). In a summary of extensive new research on the topic, Wheeler (2020) and 23 co-authors concluded that creating opportunities for a more equitable and substantive role for traditional ecological knowledge in building an evidence and knowledge base for research and decision-making can create benefits for Indigenous communities, scientists and decision-makers.

Our research assumes that adaptive responses to past climate changes are present in contemporary Native American environmental knowledge and potentially are useful today and tomorrow. American Indian cultures derived in part from ancient complex human and nature relationships, which made their resources and ways of life highly resilient (Trusler and Johnson 2008). Indian peoples thus have multi-generational histories of learning about, interacting with, and co-adapting to changes in their environments (Turner 2016). Oftentimes, they have been able to cope with environmental uncertainty, variability, and change (Wildcat 2012: 509). Indian peoples traditionally developed sophisticated connections and investments in these humanenvironment relationships (Lynn et al. 2013: 553) including deep spiritual ties with nature (Stoffle, Toupal, Zedeno 2003).

These co-adaptations with the environment are like ones documented among aboriginal peoples elsewhere. Howitt (2020), for example, describes the struggle of Australian peoples as they both grapple with the colonial society and subsequent climate changes. Like the Odawa, native people in Australia argue that their environmental knowledge is a science based on longer time periods and spatially wider ecological understandings. 
The Odawa people have resided in northern Michigan for about 600 years (Cleland 1992;

Patty 2001); before that they lived along the St. Lawrence River near the Atlantic Ocean. For much of this time they dominated trade in the Great Lakes, often traveling for months and a thousand miles in great canoes made from birch bark covering a hard wood frame (Tanner1987; Warren 1984). They could navigate by the stars at night and used seven culturally different kinds of water from boiling springs to waterfalls. They mined and traded copper from the Upper Peninsula of Michigan, they made warm homes covered with reed mats, and they defeated their enemies because they were better dreamers. Odawa people developed a complex native science of their environment (Clifton, Cornell, and McClurken 1986); and they love(ed) wild rice manoomin.

According to the Grand Traverse Bay Band of Ottawa and Chippewa Indians web site (GTB 2020):

We are the people of the Three Fires Confederacy, the Odawa (Ottawa) the Ojibwa (Chippewa) and Bodowadomi (Pottawatomi) people. Our oral history traces us back to the Eastern Coast of Turtle Island where our spiritual leaders told us that we should travel to the west until we found the food growing on the water. Our people traveled until we found wild rice growing on the water and we knew we were home.

According to elders interviewed by a group of youth at Little Traverse Bay Bands of Odawa Indians (LTBB 2005: 8)

Our history teaches us that in ancient times we lived far to the east along the Ottawa River, which is a tributary to the St. Lawrence River and Atlantic Ocean. We slowly moved toward the west, finally arriving at the Great Lakes where we lived upon Ottawa Island in northern Lake Huron, now called Manitoulin Island. That is also the place where we split into three major groups that eventually became known as the Ojibwe, Odawa, and Potowatomi. All three of these groups refer to themselves as Anishinawbek who proudly represent our culture. With these values we will move the tribes forward. 
The Odawa people were among the few Native American cultural and linguistic groups who were not relocated by the United States to new lands west of the Mississippi and Missouri Rivers (Cleland 1992). The Ottawa Tribe of Oklahoma, however, is composed of people relocated from what is now the Detroit area due to the Treaty of 1833 . Critical decisions made by their leaders were the reasons most of the Odawa people were not relocated beyond the Mississippi, as were about dozens of other Indian cultural groups. Odawa people were spared the long walk to a place they did not know because the religious and political leaders of various local Odawa groups decided to formally and publicly relinquish official symbols of leadership and religion (Karamanski 2012). This occurred during a ceremony where the religious bundles and symbols of leadership were burned, and the Odawa people agreed to relinquish their more obvious traditional ways of life and become peaceful neighbors with the United States settlers who had moved into preexisting Indian communities, farms, and hunting areas. The neighbors would eventually support the Odawa requests not to be relocated and the federal government agreed on the condition that the Odawa sign treaties of extinction.

The Odawa people living near Sleeping Bear Dunes have continued to live in their traditional lands, albeit moved away from many places they once occupied exclusively. Under extreme pressure from the United States government and facing relocation, the Odawa adapted to a new social situation. The transition from Odawa ownership and social domination in the Upper Great Lakes to one of United States citizens was largely accomplished by a series of forced Treaties $(1836,1837,1855)$ that formally terminated most of their rights as sovereign tribes. Remaining were rights to hunt in the extensive forests and fish in the many lakes and streams. Ownership of home sites and farms was problematic and occasionally whole villages would be burned out to remove the Odawa citizens from their farms and land (Stoffle et al. 2015: 24). 
From the early 1800s until modern times the Odawa people "blended" into local Euroamerican society adopting common dress patterns, going to schools and churches, and generally becoming just another citizen of the United States. They lived sub-rosa; out of sight and away from controversy, working for wages in sawmills and fish packing houses, and often living in corporate worker housing. Retaining key aspects of traditional culture became an art practiced away from their fellow United States citizens. They did not have to hide some cultural practices. They continued to make generally useful forest-based objects such as hard wood baskets and sugar molasses from the trees. Other objects such as the water-drum used in ceremony would be hidden as were the events themselves. Most medicine would be kept at home, but a few cures would be shared with neighbors. Fish would be caught, consumed in households, sold, and shared with neighbors.

The Odawa would neither be recognized as tribes nor have reservations, even though certain of their rights and their cultural recognition were written into the treaties. They would live at the edge of Euroamerican society for more than 150 years, at which time United States national relationships with Native American people shifted to neutral or even positive. Some Odawa bands sought federal recognition under the Indian Reorganization Act in 1934 and again in 1943 but these efforts were denied. In 1980, the Grand Traverse Band of Ottawa and Chippewa Indians was officially recognized as a tribe by the federal government. The Little Traverse Bay Band of Ottawa Indians and the Little River Band of Ottawa Indians were recognized in September of 1994 by President Clinton (Senate Bill 1367). The Odawa word for reservation is shkwaanagan, meaning leftovers. The new reservations were indeed leftovers of a once vast territory that had supported large Odawa populations (McClurken 2009: 53). 
Odawa Traditional Ecological Knowledge was passed from generation to generation despite living in a society that neither recognized nor approved of their culture. Specific patterns of his continuity are documented later in this paper.

Beginning in 1869 and culminating in 1890 after the Ghost Dance movement was suppressed, the Federal government passed laws against the practice of Native American religion (Wenger 2011). This federal assimilationist ideology condemned indigenous ceremonies as immoral and degrading and key in indigenous tribal systems that must be destroyed if Indians were ever to be civilized (Wenger 2011: 854). Odawa elders who were observed conducting ceremonies — especially those involving the sacred water drums — were arrested, placed in jail, and the drums destroyed. Tribal members began to hide the remaining water drums in the living sand dunes called Sleeping Bear, who were thought to protect the drums, the ceremonies, sacred plants, and the people themselves. The sand dunes continued to retain their sacred purposes, but increasingly became a region of refugee where traditional activities could be practiced sub-rosa.

\section{METHODS}

These are participatory research studies, inasmuch as they involved tribes and National Park Service personnel who influenced the focus and design of the research (Joosse et al. 2020:68). The 2014 study involved three Odawa (Anishinaabeg) tribes (1) Grand Traverse Band of Ottawa and Chippewa Indians, (2) Little Traverse Bay Band of Odawa Indians, and (3) Little River Band of Ottawa Indians. Each tribe worked on the climate change study and sent knowledgeable representatives to share TEK during field visits in the park.

SLBE data used in this analysis were collected during 95 information-sharing events in these two ethnographic studies. Information sharing events is a term of practice in the National Park Service that reflects a participatory research model where native people and the park 
identify how, when, and where to share cultural information. Fifteen sharing events were conducted during the 1998 study (Stoffle et al. 2001) and 80 sharing events were conducted during the 2014 study.

Discussion topics reflected the resource use and management interests of SLBE, the NPS regional office for Interior Regions 3, 4, and 5 (formerly the Midwest Regional Office), and the three Odawa tribes. A research team from the University of Arizona combined these interests to form a study design. These people and agencies came together in a process where all parties understood and agreed to the topics to be studied, where these studies should occur, how to develop protocols for dealing with public and confidential cultural data, and what is an appropriate report presentation format.

National Park Service consultation studies are designed to afford people the opportunity to structure the study itself, review analysis of findings, make corrections and additions, write portions of the study, and review and approve the report at the individual tribal representative and tribal government levels. Various terms are used to describe research that is methodologically structured so the people whose culture is the focus of the study have a clear voice in both the process of report production and approval. Some of the more common terms are (1) participatory ethnographic research, (2) collaborative ethnographic research partnerships (3) engaged ethnography, (4) participatory natural resource studies, and (5) indigenous knowledge inquiries. Taken together these new kinds of consultation methodologies give greater voice and agency to the people under study.

Various kinds of data are needed to prepare an ethnobotanical baseline that can be used in future discussions between a tribe and a park. The 2014 study developed two data collection forms that guided all data sharing events to address issues such as: (1) which species are both 
traditionally used and currently important, (2) for what purposes are plants used, (3) does gender influence who collects plants, (4) during what season are plants collected, and (5) what quantity of each plant is typically collected per trip. These and other topics such as traditional conservation practices were perceived to be useful when a park and a tribe begin to develop the ethnobotanical base for a possible Plant Gathering Agreement under "Gathering of Certain Plants or Plant Parts by Federally Recognized Indian Tribes for Traditional Purposes" rule 36 CFR Part 2 (Code of Federal Regulations, title 32, sec. 2.6. 2016).

A total of five habitats are analyzed here to represent the range of ecosystems found throughout the park and to study as many species as possible. The study was described in orientation meetings between tribal representatives and the park leadership. Based on their understanding of the study's purpose and their first-hand experiences in the park, tribal elders and park natural resource experts selected these habitats as sample units in the park representing a range of ecological and topographical places and species. It was especially important to study places containing traditional Odawa plant gathering areas that they have visited over generations.

Two types of data recording instruments were developed (1) the Site Form regarding the ecological complexity of specific places in the park and (2) the Plant List Form where information about plants observed or known to occur at a specific location were recorded.

The Site Form included topics such as (1) name: Odawa name or names for the place, (2) geology: what is unique about the geology of the place, (3) ecology: information about the plants as they live together and interact with the special geological features of the place, and (4) cultural uses: any special historic events that have occurred at this location.

The Plant List form was designed to inform the NPS Plant Gathering Agreement requirements (Figure 3, Figure 3b). Plants were initially identified as being in SLBE and 
traditionally used. Many of these came from the historical and ethnographic literature about the Odawa people. This list formed the basis of the SLBE data form. which had these as rows and Plant Gathering questions as columns. When plants were identified in the field as being of contemporary interest to the Odawa people, they were marked on the form along with answers to other questions.

These instruments were designed for recording tribal representatives' thoughts and assessments while visiting study areas. Copies of all procedures for data recordings, written questions, and tape recorders were presented to tribal representatives at their field orientation. No questions were raised as to the appropriateness of these discussion points or how the studyspecific conversations would be recorded. Tribal participants were assured that they could raise new discussion points during the field session.

\section{FINDINGS}

Here we present specific field observations and evaluations provided by Odawa tribal representatives. Subsequently, the tribes agreed upon findings about observed climate change and its impacts on culturally significant local plants and ecosystems. The study documented 288 traditional Odawa use plants and studied climate effects on five habitats located in SLBE. The categories of information about these plants and how they would be gathered and how much would be collected are needed for a Plant Gathering Agreement under the NPS Plant Gathering Rule.

Odawa perceptions of climate change were often poignant, reflecting noticeable changes occurring at both small and large spatial and temporal scales. These are illustrated by changes to trees and spring greens, streams and lakes, and fish and birds. Odawa representatives focused on climate change impacts on culturally central plants like maples, changing lake and stream levels 
due to new weather patterns, and the rise of insects that bore and kill trees. Global warming causes extremes in weather, hot one year and cold another, record snow levels followed by little snow for years, and lake levels that fall but then rise beyond experience.

Odawa representatives expressed concerns that habitats, not just individual plant species, are experiencing the impacts of extreme climate events such as warming, cooling, drying and shifting seasonal weather. The natural vegetation of the Upper Great Lakes region is composed mostly of forests, with pine dominating in north-central and northwestern Michigan. Other habitats include marshes, bogs, swamps, and small isolated prairies (Yarnell 1964:4).

Figure 4 divides the SLBE ecology into five types of habitats that were perceived by tribal representatives to be both culturally important to Odawa people and threatened by climate change. These habitats included: (1) Upland Forest; (2) Marsh, Swale, and Wetland; (3) Mesic Sand Prairie; (4) Dune-Forest Transition Zones; and (5) Coastal Dunes and Beaches.

Representatives both described the habitats and how these contributed to Odawa culture and how climate change had changed the habitats.

Analysis of the plant types affected by climate change are presented in Figure 5. These categories include 115 species: (1) 62 Plants/Flowers, (2) 40 Trees, (3) six Reeds, (4) four Fungi, and (5) three Ferns. Of the 288 traditional and contemporary use plants identified by Odawa representatives, $40 \%$ were observed as being influenced by climate change.

\section{Habitat \#1: Upland Forests}

According to tribal representatives the habitat with the largest number of species experiencing threats due to changing climate is the upland forest, which includes a variety of hardwoods, shrubs, mosses, fungi, and flowers. The nutrient-rich soil promotes plant growth and allows trees to deeply attach their roots for stability. The majority of the upland forests have 
extensive stands of mature beech and sugar maple hardwoods, but also there is hemlock, white pine, basswood, white ash, red oak, ironwood, and black cherry species (Sleeping Bear Dunes National Lakeshore 2019).

Odawa representatives identified 45 Upland Forest plant types threatened by climate change (Trosper and Parrota 2012). Study areas at Pyramid Point, Glen Lake Sugarbush, and Platte River Point provide evidence of changes to many upland forests. Maple (Acer ssp.), birch (Betula ssp.), and ash (Fraxinus ssp.) were identified as experiencing signs of decline, poor health, and other disruptions in seasonal availability related to climate change.

Maple trees are culturally central to Odawa people, who use the sap in the spring for food and medicine. Maple wood is used for crafts and construction. The inner bark is used for medicine and cough syrup.

The process of harvesting maple sap, also known as sugaring, requires freezing temperatures at night with warming temperatures during the day. If the temperatures warm six to ten degrees in winter, negative impacts are possible (Kling et al. 2003). The cultural specification of March as the sugaring month may no longer be true. The Little Traverse Bay Bands have a book called Native Plant Initiative says that the Anishnaabemowin name for maple syrup is ziinsiibaakwad and the month of March is known as the Maple Syrup Gathering Moon, or Ziisiibaakade Giizis (Pilette 2009: 24). Odawa cultural traditions maybe forced to shift when they hold sugaring camps, because cooling and warming are needed to get sap flowing. The camps may have to occur in February or April as opposed to March. Shifting the time of sugaring is culturally important because it is a key point in the traditional ceremonial cycle.

Wiigwaas, or paper birch, plays a vital role in Odawa culture as well as maple. Birch bark serves in the production of crafts, construction, canoes, and other uses (Figure 6). Much like 
maple sap, a birch tree can be tapped for sap which is used for candies, syrup, and sugar (Great Lakes Indian Fish and Wildlife Commission 2001). Likewise, birch trees serve as a complimentary plant for maple sugaring, with storage containers and baskets made from birch bark used to store sugar, sap, and syrup. Therefore, droughts related to climate change pose a serious threat to both maple and birch trees and associated ceremonies (Kling et al. 2003).

Odawa Comments:

- $\quad$ They used to sugar at the end of February, March. I think this year they didn't do it until April, but we had a harder winter, a longer winter, and we had the longest snow, and even our Great Lakes froze over for the first time in a long time. We're talking about the big waters, not the little lakes around here. So it got frigid here. That has had an impact on some of the plants and the trees, so with a longer colder winter we weren't able to start doing maple sugar until April, in fact I think it just got done and we're in mid-May now. So I do think, yeah, obviously the climate does have an impact on our medicines and our trees.

- It's not like it was in the old days, I think the nights and days aren't as cold as they used to be. That's what brings that sap up into the trees. It draws it and pushes that sap up. I used to hear those trees snap up there in the woods because, those maple trees, that sap would freeze and crack the trees. I used to have to wait for the bus and hear the trees out there. It used to be cold. I remember days when you go outside and breathe and your breath would freeze.

- If we had maintained the low temperatures that we were having this year for a longer duration, it would really have knocked out the Emerald Ash Borer that would have been great. Since we don't maintain or can't maintain those cold temperatures for long periods anymore though they [Emerald Ash Borer] are able to hang on. The Emerald Ash Borer showed up in the early 1990's but we didn't know the extent of the damage until 1997 or 1998. Now it's too late, they devastated the black ash stands across the state. In response to the devastation of the black ash we've started collecting seeds, and put them in a seed bank. Maybe we can restart once this pest passes.

Ceremonies of all kinds especially those associated with medicine require certain kinds of containers, tools for stirring, and mats for placement in order that the ceremonies will be 
successful. So, climate change is reducing or eliminating the performance of traditional curing ceremonies.

\section{Habitat \#2: Marshes and Wetlands}

Wetlands and Marshes have nutrient-rich soils that are generally saturated and thus support an abundant growth of reeds, shrubs, flowers, and aquatic plants. Many of the plants identified by Odawa representatives grow in slow-moving or still waters characteristic of swamps, swales, and wetland areas (Figure 7).

Wild rice (Zizania ssp) is a key wetland resource. Although not now available within SLBE, it is being considered for reintroduction. A wetland habitat is a requirement for wild rice to grow, but recently the temperatures and availability of water have impacted where it can grow in the region. Warming winters and changes in water level are reducing the habitat of wild rice.

Wild rice is a pillar of cultural health for the Anishinaabeg people, and any decline in wild rice quality or availability negatively affects their well-being.

Traditional Ojibway (Odawa) life elevates rice above being for consumption or barter. Stories and legends reinforced the ceremonial uses of manoomin. Taboos and proscriptions against eating it at certain times show the centrality of wild rice in Ojibway culture (Vennum 1988: 58).

The act of harvesting plants "encompasses the holistic aspects of wellness and includes physical, emotional, psychological, and spiritual realms of the individual and community" (Lynn et al. 2013: 548). Manoomin is this type of sacred resource. Even sharing the legends associated with the plant are reserved for powerful people and they only do so during special times of year (Vennum 1988: 59).

Climate change threats to wild rice can harm transmission of cultural knowledge and learning of values. Warmer temperatures can cause damage by reducing water levels, reducing 
seed dormancy, favoring invasive and outcompeting plants, and creating an environment more conducive to brown spot disease (Cozzetto et al. 2013: 71).

\section{Odawa Comments:}

- There's this patch where we used to get that Sweet Flag. So, my sister and I tried to gather that last August, which is about the time when you want to collect it, August, late July, but it was all dried up, that spot where we always got the Sweet Flag. It reminds me because the ground was kind of like this [at Platte River Point], it was wet and moist, but that ground was just, it reminded me of desert sand because it was all dried up, it was really thriving back in 1998.

- I've watched the lake level here at Lake Michigan drop. Maybe now there are spots where water used to meet, say, within 5 or 6 feet of the road, M-22, and up until this year you could see for 200 yards a dry, stony shoreline before you get to the water. I have noticed a lot hotter summers up until right now too. I remember last year being in the 80s, mid 80s right now, about the end of May. I mean, that's the kind of the stuff that really comes to the forefront for me, immediately recognizable as the winters and the summers are changing.

- I would say it's dryer there than it used to be, that's what I think. Last winter and this summer have been very different than the last 15 years. The temperatures have changed, it's jumping all over, unpredictable. That has to have an effect on the plants that grow here, plus the acid rains that bombard them.

- Climate change is drying up the wetlands. These plants really need a high amount of moisture and water, like mesquiguish and wiikehn.

\section{Habitat \#3: Mesic Sand Prairies}

Mesic Sand Prairies have rich and moist soils, and are host to a diversity of wildflowers, grasses, and low growing shrubs like blueberry bushes. Odawa representatives identified 19 plants in grass meadow habitats that they observed being impacted by climate change including several types of berry bushes, mushrooms, and many medicinal flowers. Drought, cooling temperatures, and prolonged periods of freezing temperatures were described as some of the main climate related changes affecting the mesic sand prairie areas. 
The park has clearings that are open mesic sand prairies, many of which were caused by agricultural and logging in the early $20^{\text {th }}$ century. Traditionally, however, such habitats were created by selective Odawa burning. Many of the plants, like the berries, require burning to thrive (Trusler and Johnson 2008; Stoffle et al. 1998).

\section{Odawa Comments:}

- We've been having dryer spring seasons, because we haven't had that snow packed up until this past winter [2013-2014]. And... you need kind of that moist, wet spring to get a good bounty of the morel mushroom, because if it's really dry you're just not going to get it like you had before.

- Wow, that is a spring morel [mushroom]! Finding it here in September is insane!

- Plants used to come up fuller and healthier in nice open areas like this [walking up to Pyramid Point]. We only see that if it rains hard. There is less water overall. The plants as a whole are not growing as well as they used to.

\section{Habitat \#4: Dune-Forest Transition Habitat}

The Dune-Forest Transition Zones (Figure 8) contains seven plants, identified by Odawa representatives as threatened by climate change. This habitat is defined as an open dune area that is typically nestled within a forested landscape, with the dune sands supporting a variety of forest types (Michigan State University Extension 2014). Exposed dunes are dominated by grasses and shrubs located on wind-deposited sand formations near the Lake Michigan shoreline. Dune formation and the distribution of plants are strongly affected by lake-driven winds. As the dunes stabilize farther from the foredune, forests begin to develop. Typically, pines, including Jack pine (Pinus banksiana), white pine (Pinus strobus), and red pine (Pinus resinosa), are among the first to establish (Albert 1999: 3). Areas studied included Pyramid Point and near Platte River Point.

\section{Odawa Comments:}


- A lot of trees are coming down because of wind, look at these [trees] up here on the bluff, falling over now with roots hanging out. We actually had droughts. For the last couple of the years for the summer we don't have any rain, so we've seen less precipitation. Less water is bad for tree roots, they aren't holding on well, so they just blow over.

- My mom said it's gotten a lot windier in the past ten years. More severe wind, especially along the lakeshore.

- Summers have changed a bit, [they are] slow to come. It's pretty obvious that there are climate changes happening. It influences a lot relating to plants, like where and when you can find them, and also what types of plants start crowding and taking over where Native plants were previously. If it warms up we have new plants that move up here, you know, stuff that didn't used to grow here.

\section{Habitat \#5: Coastal Dune and Beaches}

According to one Odawa elder, in SLBE there are spiritual places used for healing ceremonies, vision questing that culturally center the Odawa people (Figure 9). Plants growing on the dunes have special strengths and uses. The name of the park reflects the ancient oral heritage stories of bears.

Coastal dunes and beaches have a soil that is low in nutrients and made up of granular silica. Sand from these dunes and beaches blows easily and changes the contour of the land. These habitats experience the direct impacts of inclement weather more than other habitats because there are no large trees to provide a canopy shelter. The plants that grow in dune-beach habitat have deep roots, so they are better able to endure the harsh environmental conditions.

Dune systems are well suited for the study of succession and ecological change because they change rapidly. When Lake Michigan levels are lower the beaches and dunes are exposed making new sand spits, sand bars, and foredunes. These are rapidly colonized by beach grass.

Points where streams flow into Lake Michigan often experience sand build up due to blowing sands that choke off or deflect the stream flow. This is exemplified at the Otter Creek 
Mouth during different times of the year (Figure 10). Storms and high lake levels can cause even more rapid changes in plant communities (Michigan State University Extension 2014). Within one or two human generations the vegetation can change from beach grass, to shrubs and trees. Fish spawning is directly impacted by modifications to stream flows.

Culturally significant medicinal plants grow in the beach area at Otter Creek Mouth and Good Harbor Beach. Here beach pea, honeysuckle, bearberry, and pitcher's thistle are all threatened by climate changes including rainfall and lake levels, winds and storms, and seasonal temperatures.

\section{Odawa Comments:}

- A lot of the plants we need grow on these dune areas, around here [Otter Creek Mouth]. It's getting harder and harder to find them [plants], and some plants we can only pick right when we need them, you can't pick them ahead of time and if they aren't there right when we need them, then that's really a crisis.

- The plant that comes to mind as really limited and hard to find anymore is Pitcher's Thistle [Cirisium pitcheri], if you're going to find it, then it should be around here, this type of dune area [Otter Creek Mouth].

- We had some brutal storms this summer, things I've never seen before and the older people had never seen before in their lifetime. I live in Harbor Springs, MI and we had a giant wave come off Lake Michigan, nothing like this has ever happened before. It was huge, and powerful, it wiped out the city dock and overturned the big boats, like fishing boats, and people's big yachts, just flipped them over. It left debris, and dirt, and all sorts of sandy kinds of stuff around the harbor. I don't know what's causing that strange type of event out on the water, but it has to have something to do with big winds.

\section{DISCUSSION}

The SLBE studies of Odawa people and their knowledge of climate change achieved all of the stated project goals. The first was to determine what kinds of climate change data are available by talking with contemporary Odawa tribal representatives. Among the 288 identified traditional use plants in the park, 115 were known to have been influenced by climate change. 
All five habitats studied were known in specific ways to have been influenced by climate change. Knowledge of climate change is widely recognized by tribal members as a part of contemporary Odawa environmental knowledge.

A second goal was to document Traditional Ecological Knowledge of plants, ecosystems, and patterns of contemporary use. An ethnobotanical data collection instrument was developed and used to record observations about traditional and contemporary use plants that were identified in person during field visits to the park. This form and way of gathering data was seen as a model for collecting ethnobotanical data and was so referenced in the NPS guidelines for establishing a Plant Gathering Agreement between a tribe and a park.

These studies also documented cultural persistence in the face of extreme suppression and exclusion. While these studies have only identified a portion of the contemporary knowledge of the Odawa people who are members of these three tribes, clearly the plant and habitat knowledge shared by tribal representatives is impressive. To tie it closely from place to place and from plant to plant to the process of climate change in many of its dimensions is a special observation. At a more abstract level, these findings suggest the further question of how the Odawa accomplished the retention of Traditional Ecological Knowledge during the long and painful transition from aboriginal occupants of traditional homelands to contemporary tribal members on reservations. Today the people of these three reservations reach out to federal and state land and water managers to find a renewed role in the co-management of aboriginal resources.

These SLBE studies document that Odawa people have extensive knowledge of their traditional lands and resources and that they are committed to working with the NPS to preserve these for future generations. The process of knowledge transfer from a traditional people to a 
federal agency, however, requires certain understandings. The first of these is to understand how traditional knowledge is acquired, refined, and maintained through various cultural practices. The second is how to take ancient knowledge and apply it to future management decisions.

\section{Traditional Science Embedded in Culture}

The Odawa bring to the preservation challenge poised by climate change an estimated 600 years of in-place learning and adaption to shifting weather and climate conditions. Their environmental understandings are extensive as is indicated in this ethnographic study where they provided detailed knowledge of (1) 288 plants, (2) the spawning of various fish species, (3) the biology and physical ecology of five diverse habitats, and (4) the seasonal movements of water, sand, and wind.

This is native science. Berkes, Colding, and Folke (2000) document that Traditioal Ecological Knowledge often represents observations acquired over thousands of years due to direct contact with the environment. Day to day, however, this knowledge base grows as new observations are made and then added. It is not until a people have worked with and learned from their environment for five generations (about 125 years) that "they have a firm information base about the environment and how to use the land without hurting it" (Stoffle et al. 2003: 104). Traditional Ecological Knowledge thus includes in-depth understandings of specific biological entities (plants, mammals, birds, insects, fish) and how these are related to physical entities (rocks, bodies of water), landforms (mountains, isolated hills, unusual rock formations), and meteorological phenomena (Pierotti 2001: 9).

Developing indigenous knowledge generally requires 16 generations (more than 400 years) of learning from and co-adapting with environmental events in the same ecosystem (Stoffle et al. 2003: 106). The Odawa people have lived much longer in the Sleeping Bear Dunes 
area. With knowledge comes a commitment to the science methods that previous generations used to learn and adapt; suggesting "if you follow 'our ways' you will always have food, shelter, and health, and the environment will be in balance" (Stoffle et al. 2003: 106).

The Odawa have learned to be resilient to past climate changes; however, there are new threats. If a powerful and culturally central plant species has not grown abundantly enough to harvest, aspects of traditional life cannot be taught to younger generations and the species is not available for use and ceremony (Lynn et al. 2013: 548). If a certain tree is not available for making a medicine basket then the curing ceremony cannot be accomplished even if the medicine is available. Because knowledge involves both sacred and secular interpretations of nature, climate change potentially can have a negative effect on the performance and intergenerational transference of Odawa religion.

Climate changes also affect tribal sovereignty including treaty rights, federal policies, and federal trust responsibilities that support tribal access to cultural resources (Voggesser et al. 2013: 622). Changes to the access and availability of natural resources can cause the "erosion of traditional practices and knowledge" (Lynn et al. 2013: 548). The new NPS Plant Gathering Rule is designed in part to mitigate this problem.

\section{Science Partnerships}

Odawa concerns expressed in these studies illustrate the small and large-scale impacts of changing climate. Odawa people with plant and animal knowledge have observed increasing trends in climate change over at least the last fifty years. Activities like maple sugaring no longer occur at the culturally prescribed time. With almost three hundred contemporary use plants and many habitats being threated, Odawa people are concerned for their future and wish to engage 
with SLBE managers to assure that these natural resources will be there to support the cultural continuity of new generations.

There are various epistemological divides between native science and western science (Agrawal 1995; Stoffle et. al 2020); a notion used here to explain why heritage environmental communication skills are essential for participants to understand and believe each other (Stoffle, Arnold, and Bulletts 2016). Critical here is how data are acquired and interpreted. Ancient and contemporary Odawa knowledge derives from natural observations and these often are expressed as spiritual understandings. If traditional people are to help apply the lessons from their past, their knowledge must be respected and trusted by contemporary park managers and scientists. This does not imply that one science should in any way replace the other but instead doubts should be suspended, and efforts made to translate understandings into each other's paradigms.

The findings of these two studies complement decades of research on the subject by scholars around the world. In a 2008 panel on the topic sponsored by the American Museum of Natural History 57 indigenous narratives were recorded describing climate change and its impacts on indigenous peoples and their environments (Alexander et al. 2011: 479). Still there sometimes is a reluctance by land managers to accept indigenous science observations until confirmed by western science (Brook and McLachlan 2005). Munshi et al. (2020:573) argue that top down western science must be balanced with understanding of how local people understand climate change; thus, there is a need to engage with the culture of the everyday lived experiences of people. Clearly studies such as these funded by and co-produced by the NPS lay a foundation for mutual respect and co-management. 


\section{Maps and Figures}

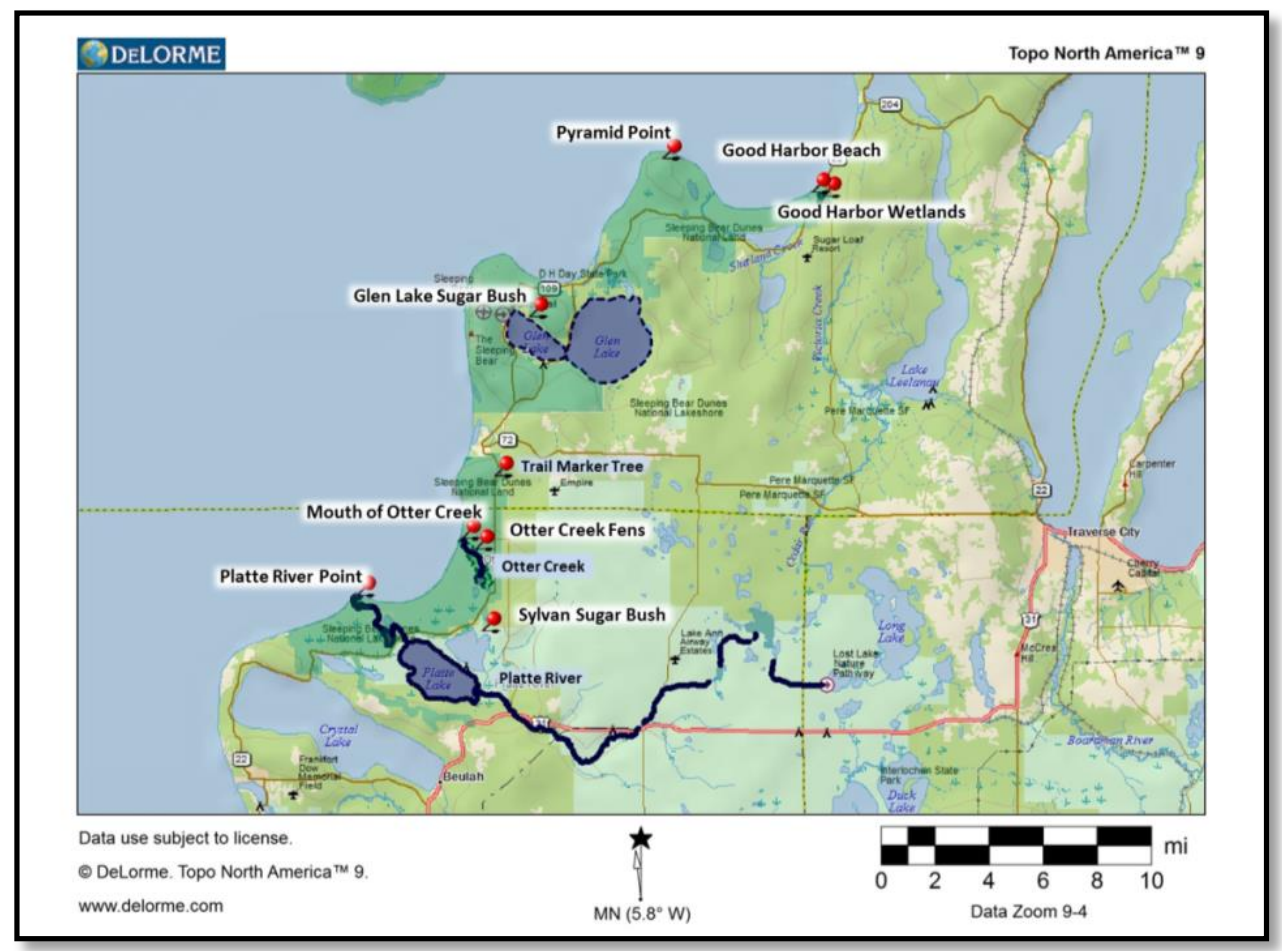

Figure 1: Study Areas in Sleeping Bear Dunes National Lakeshore 


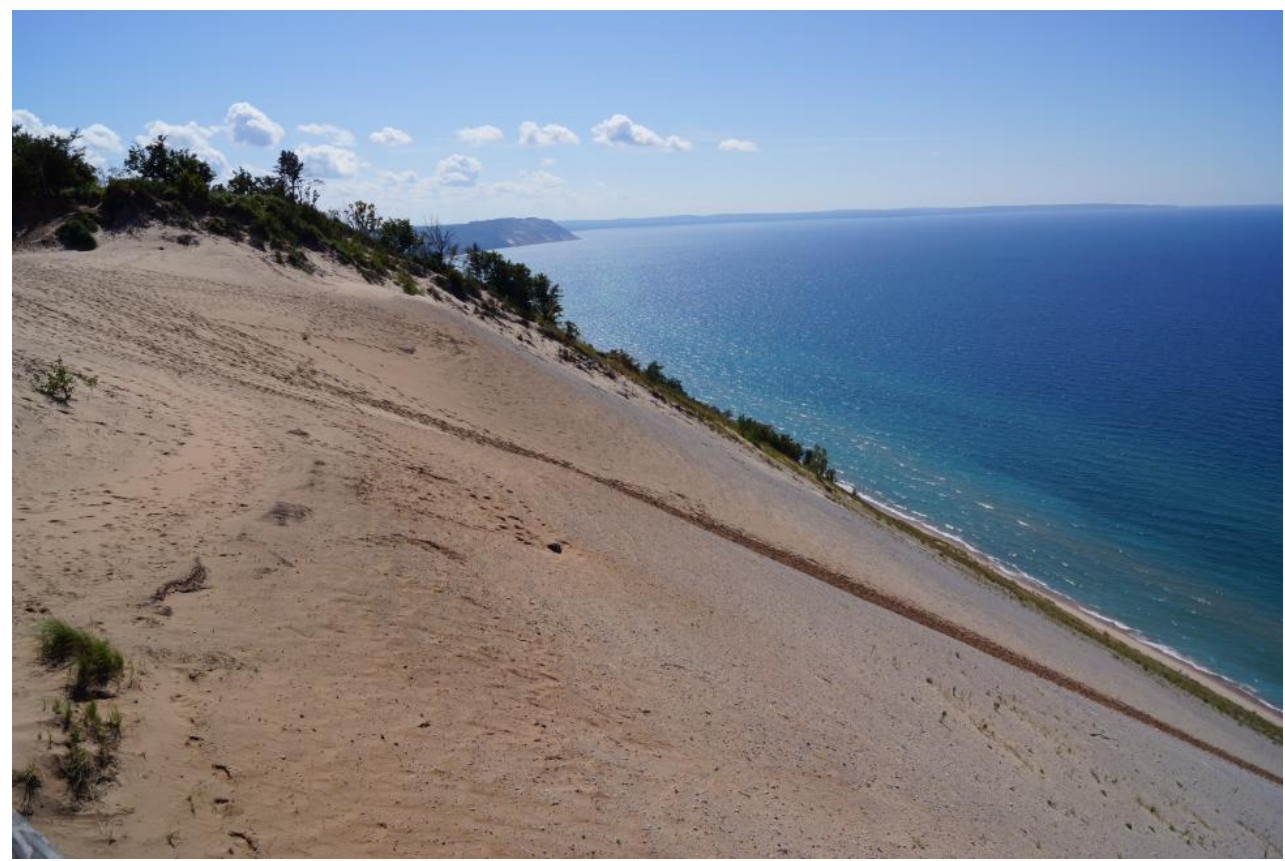

Figure 2: Sleeping Bear Dunes and Lake Michigan 


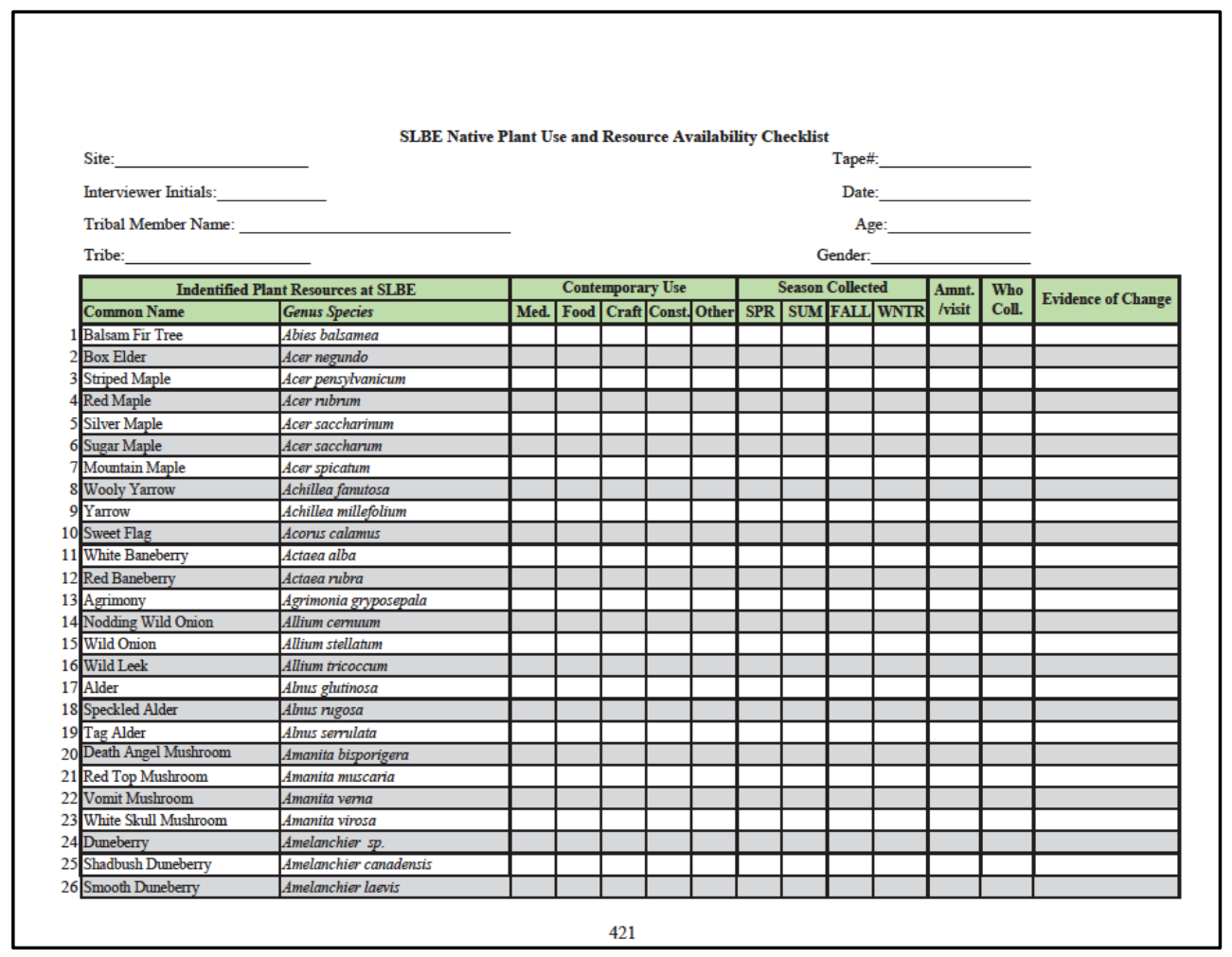

Figure 3: Native Plant Use and Resource Availability Checklist 


\begin{tabular}{|c|c|c|c|}
\hline Scientific Name & Acer rubrum & \multicolumn{2}{|l|}{ Contemporary Use Category: } \\
\hline Common Name & Red Maple & \multirow{2}{*}{\multicolumn{2}{|c|}{ 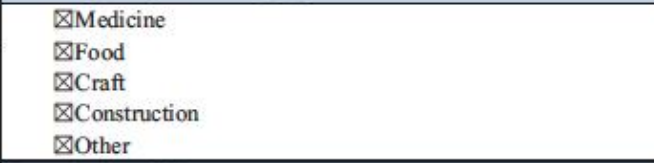 }} \\
\hline \multirow{4}{*}{ Odawa Name } & \multirow[b]{3}{*}{$\begin{array}{l}\text { Zhiishiigimiiwanzh, -iig } \\
\text { (Meeker et al. 1993) }\end{array}$} & & \\
\hline & & Description of Uses: & \\
\hline & & \multicolumn{2}{|c|}{ - We use maple as a medicine and food. } \\
\hline & & \multirow{2}{*}{\multicolumn{2}{|c|}{$\begin{array}{l}\text { LTBB Native Plant Initiative (2009) } \\
\text { - Food (syrup, less preferred than Sugar Maple, which has a } \\
\text { higher sugar content); medicine; firewood; utility (e.g. } \\
\text { lodge frames); artwork. }\end{array}$}} \\
\hline Ecosystem & Aspen Birch Forests & & \\
\hline Status in Park & Present & & \\
\hline \multirow{4}{*}{\multicolumn{2}{|c|}{ istin }} & \multicolumn{2}{|c|}{ Evidence of Change to This Plant in This Area: } \\
\hline & & $\begin{array}{l}\otimes \text { Climate Change } \\
\square \text { Lack of Traditional Use } \\
\text { \Overusing by People } \\
\text { \Over-Grazing or } \\
\text { Over-Foraging }\end{array}$ & $\begin{array}{l}\otimes \text { Pests } \\
\text { Pollution } \\
\square \text { No Influence } \\
\square \text { Combination }\end{array}$ \\
\hline & & $\begin{array}{l}\text { Seasons When this Plant is } \\
\text { Collected: }\end{array}$ & $\begin{array}{l}\text { Amount Collected at One } \\
\text { Time: }\end{array}$ \\
\hline & & 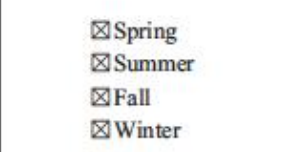 & $\begin{array}{l}\square \text { Handful } \\
\square \text { Bucket } \\
\square \text { Bushel Basket } \\
\text { 冈More }\end{array}$ \\
\hline
\end{tabular}

Figure 3b: Red Maple Entry from Plant Appendix 


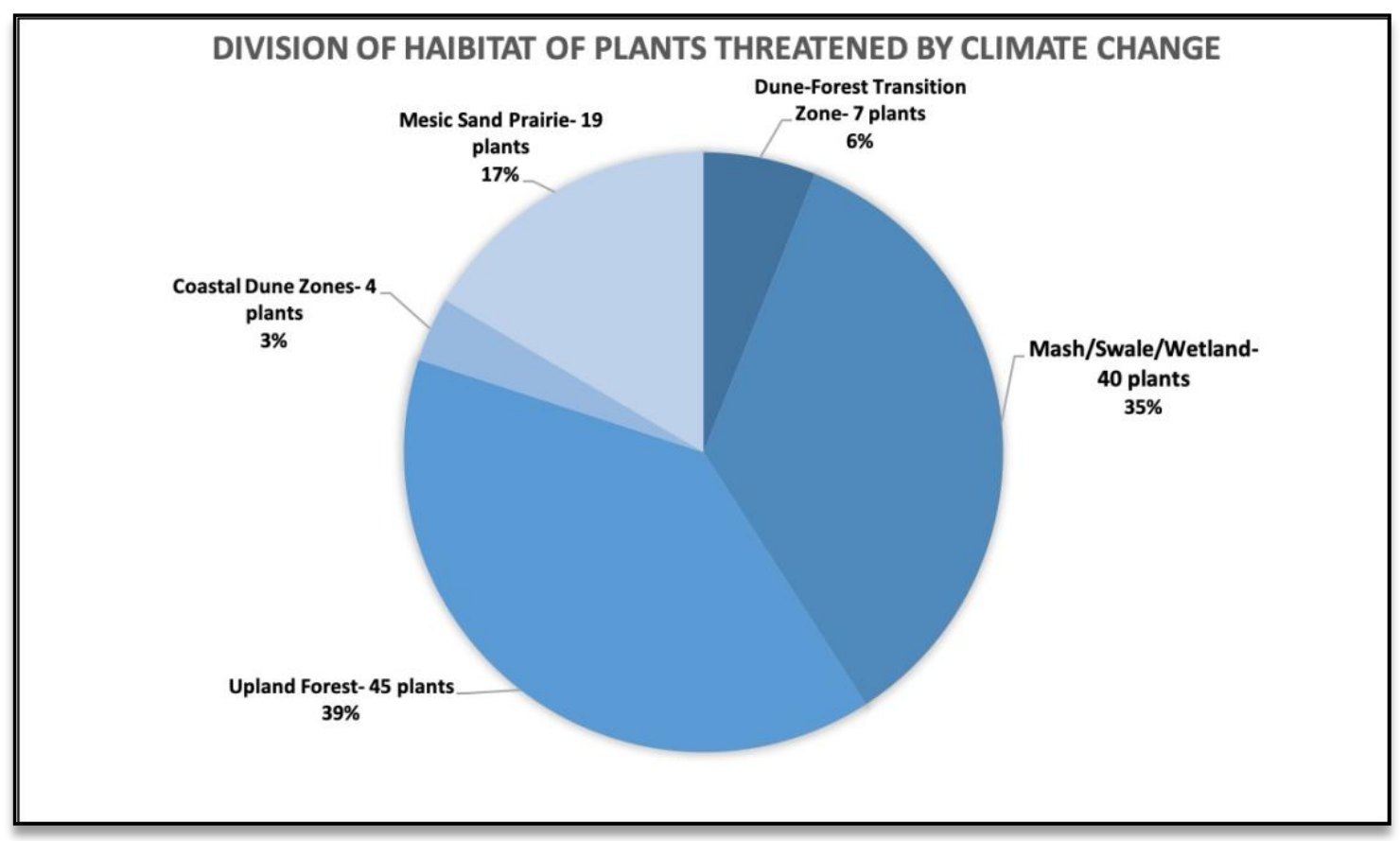

Figure 4: Division by Habitat Threatened by Climate Change $(\mathrm{N}=15)$ 


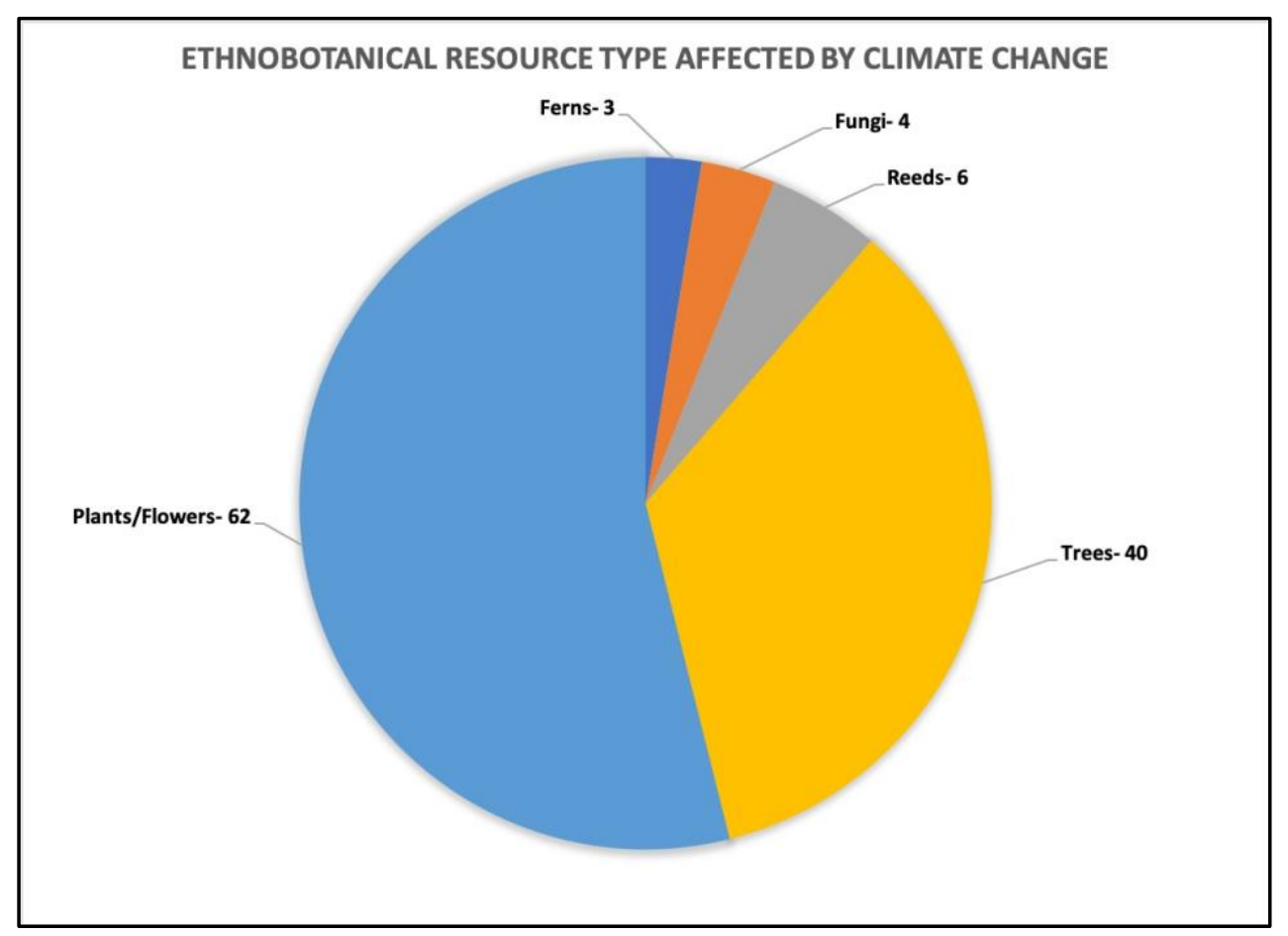

Figure 5: Ethnobotanical Resource Types Affected by Climate Change (N=115) 


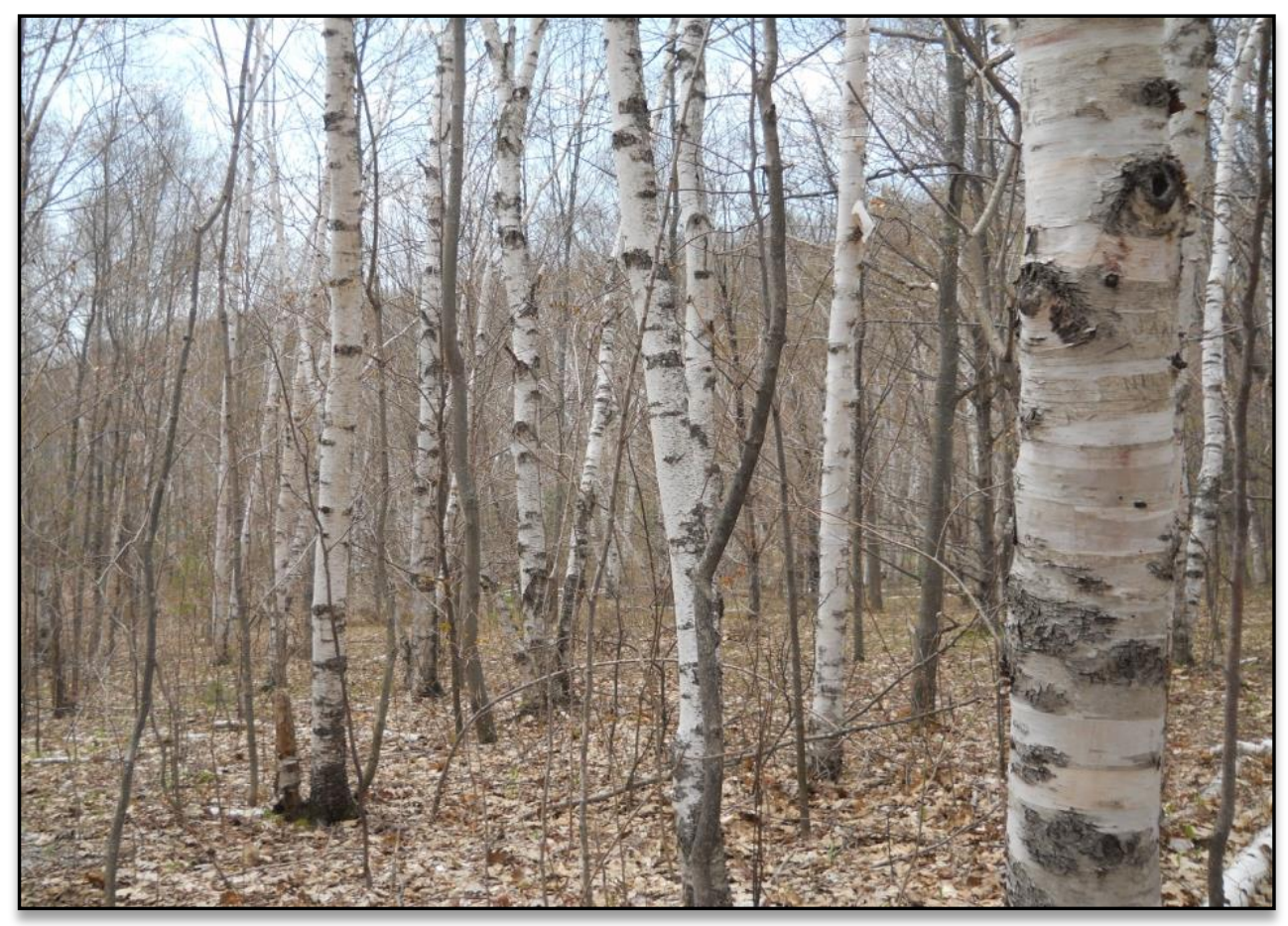

Figure 6: Paper Birch Growing at Pyramid Point SLBE 


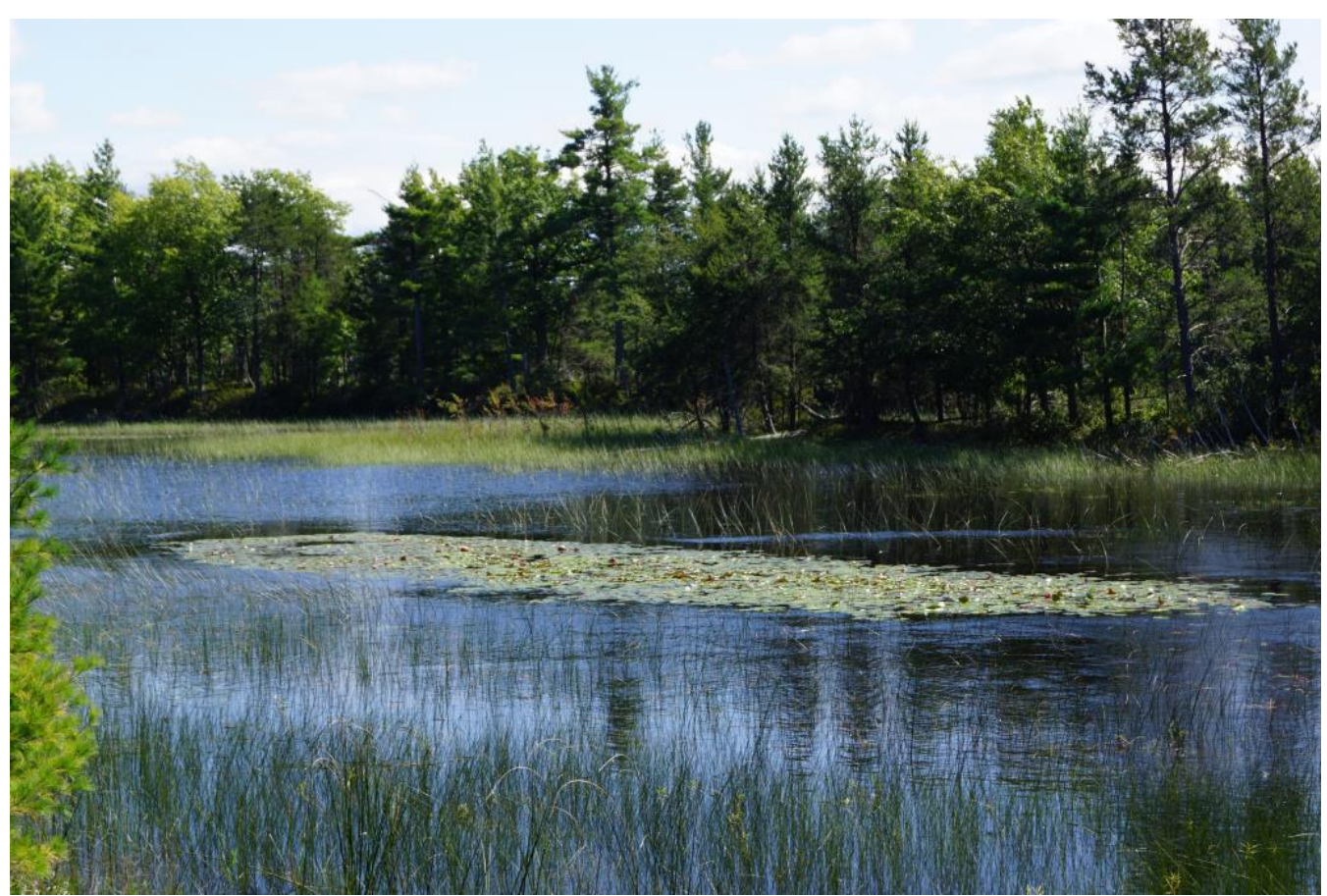

Figure 7: Swale in SLBE 


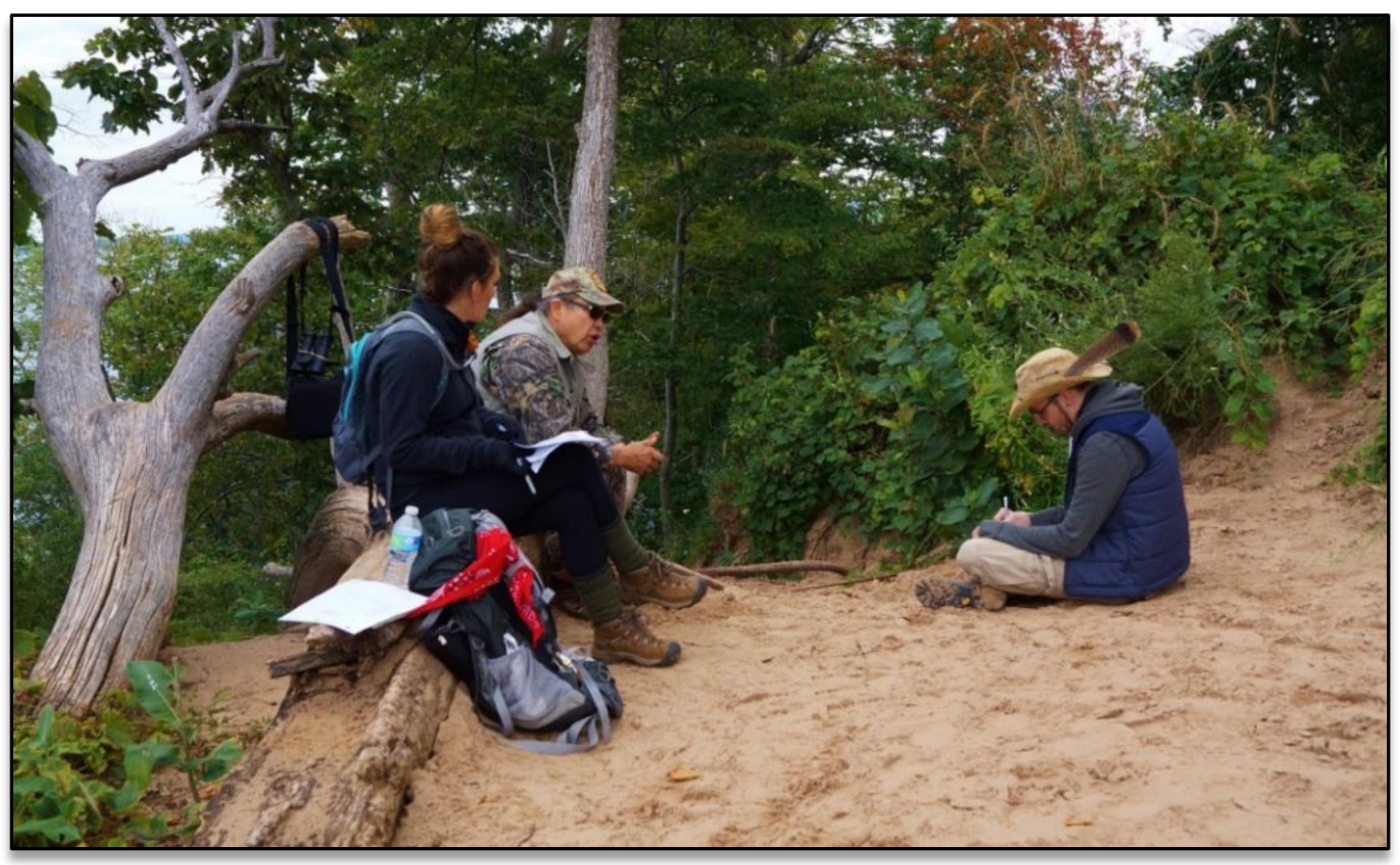

Figure 8: Talking about Dune-Forests at Pyramid Point 


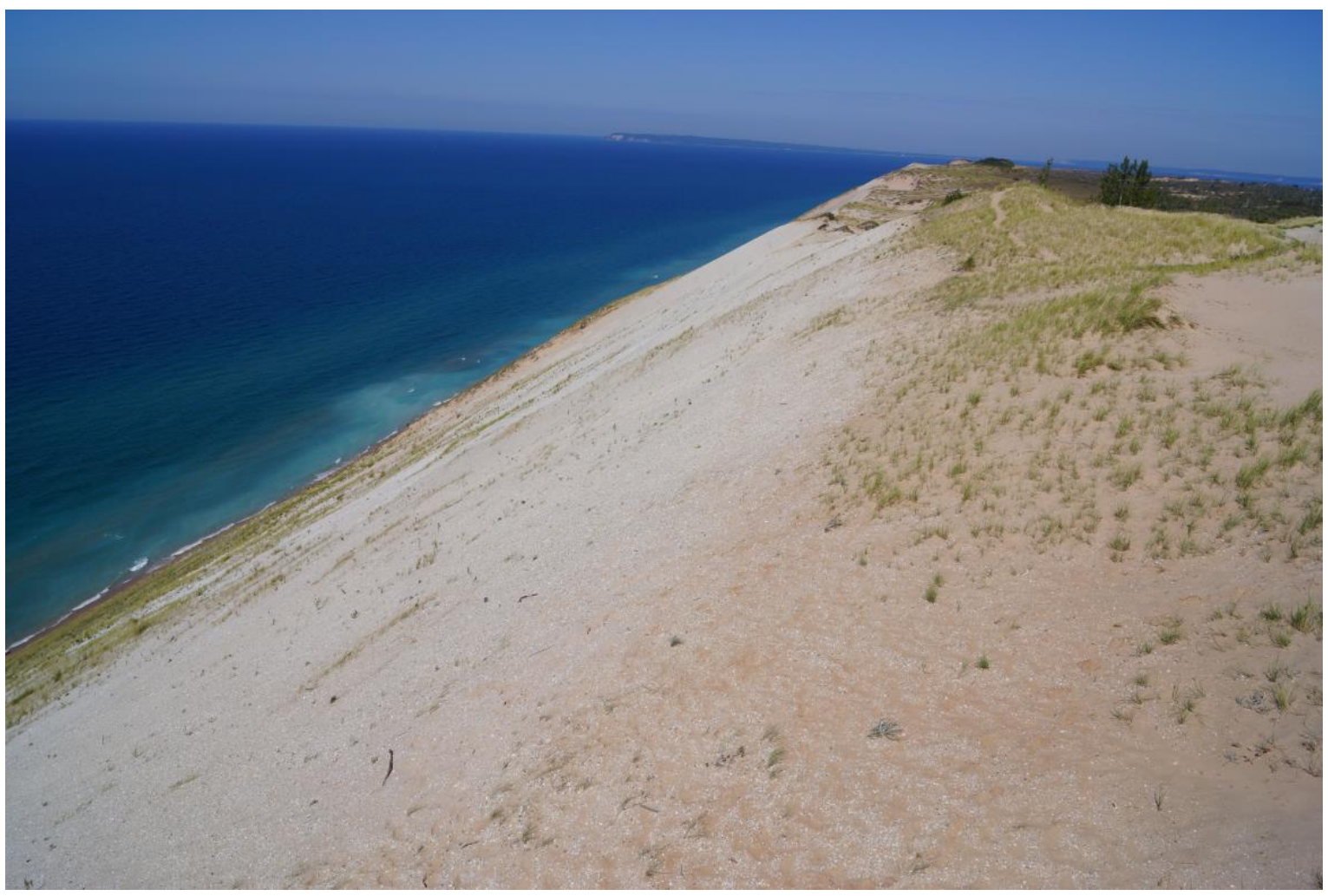

Figure 9: Coastal Dune at SLBE 


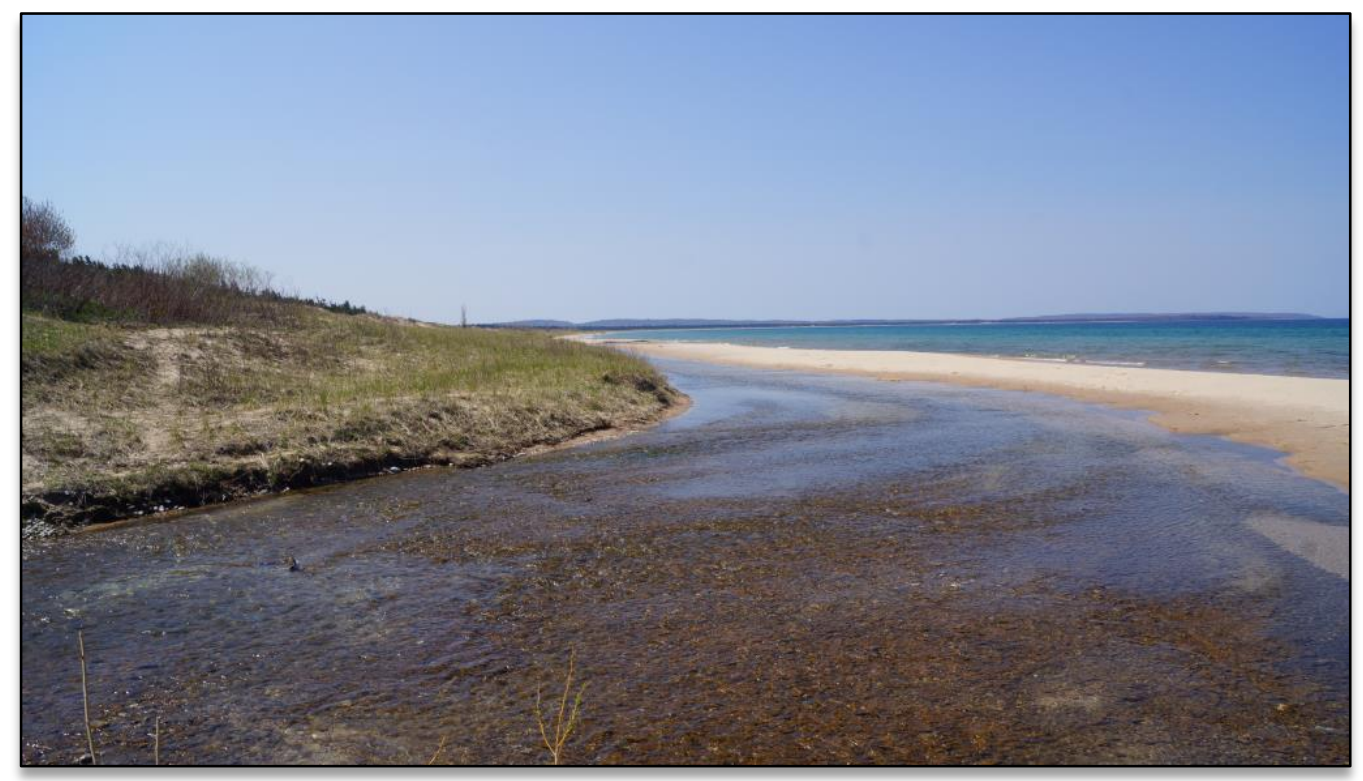

Figure 10: Lake Michigan and Otter Creek Mouth, SLBE 


\section{References Cited}

Agrawal, A. 2009. Dismantling the Divide between Indigenous and Science Knowledge. Development and Change 26(3): 413-439. DOI: 10.1111/j.1467-7660.1995.tb00560.x

Albert, D. A. 1999. Natural Community Abstract for Open Dunes. Michigan Natural Features Inventory. Lansing, MI. http://mnfi.anr.msu.edu/abstracts/ecology/open_dunes.pdf, Accessed September 2019.

Alexander, C., N. Bynum, E. Johnson, U. King, T. Mustonen, P. Neofetis, N. Oettle, C.

Rosenzweig, C. Sakakibara, V. Shadrin, M. Vicarelli, Jon Waterhouse., B. Weeks. 2011. Linking Indigenous and Scientific Knowledge of Climate Change. Bioscience 61(6): 477-484. DOI: 10.1525/bio.2011.61.6.10

Berkes, F., J. Colding, and C. Folke. 2000. Rediscovery of traditional ecological knowledge as adaptive management. Ecological Applications 10(5): 1251-1262 DOI 10.2307/2641280

Berkes, F. 2018. Sacred Ecology: Fourth Edition. New York, NY: Routledge. DOI: $10.4324 / 9780203123843$

Brook, R. and S. McLachlan. 2005. On using expert-based science to "test" local ecological knowledge. Ecology and Society 10(2): r3. [online] URL:

http://www.ecologyandsociety.org/vol10/iss2/resp3/

Cleland, C. 1992. Rites of Conquest: The History and Culture of Michigan's Native Americans. Ann Arbor, MI: University of Michigan Press. DOI: 10.3998/mpub.9272

Clifton, J., G. Cornell, and J. McClurken. 1986. Michigan Indian Press, Grand Rapid Inter-Tribal Council. Grand Rapids, MI: West Michigan Printing.

Cozzetto K., K. Chief, K. Dittmer, M. Brubaker, R. Gough, K. Souza, F. Ettawageshik, S. Wotkyns, S. Opitz-Stapleton, S. Duren, and P. Chavan. 2013. Climate change impacts on the water resources of American Indians and Alaska Natives in the U.S. Climate Change 120(3): 569-584. DOI: 10.1007/s10584-013-0852-y

Fox, D. 2007. Back to the No-Analog Future? Science 316: 823-826. DOI: $10.1126 /$ science. 316.5826 .823

Glassberg, D. 2014. Place, Memory, and Climate Change. The Public Historian 36(3): 17-30. DOI: $10.1525 / \mathrm{tph} .2014 .36 .3 .17$

Great Lakes Indian Fish and Wildlife Commission. 2018. Climate Change Could be Changing the Face of Indian Country and the World.

https://www.indiancountrynews.com/index.php/news/wildlife/14641-great-lakes-indian-fishand-wildlife-commission-has-team-working-on-studies-climate-change-could-be-changing-theface-of-indian-country-and-the-world. Accessed September 2019. 
Howitt, R. 2020. Decolonizing People, Place and Country: Nurturing Resilience across time and Space. Sustainability 12, 5882: 1-16. DOI: 10.3390/su12155882

Joosse, S., S. Powell, H. Bergeå, S. Böhm, C. Calderón, E. Caselunghe, A. Fischer, A. Grubbström, L. Hallgren, S. Holmgren, A. Löf, H. Nordström Källström, K. Raitio, S. Senecah, C. Söderlund Kanarp, E. von Essen, L. Westberg, and M. Westin. 2020. Critical, Engaged and Change-oriented Scholarship in Environmental Communication: Six Methodological Dilemmas to Think with. Environmental Communication 14:1-14. DOI: 10.1080/17524032.2020.1725588

Karamanski, T. 2012. Blackbird's Song: Andrew J. Blackbird and the Odawa People. East Lansing, MI: Michigan State University Press.

Kling, G., K. Hayhoe, L. Johnson, J. Magnuson, S. Polasky, S. Robinson, B. Shuter, M. Wander, D. Wuebbles, and D. Zak. 2003. Confronting Climate Change in the Great Lakes Region: Impact on Our Communities and Ecosystems. Washington, D.C.: Union of Concerned Scientists, Cambridge, Massachusetts, and Ecological Society of America.

Lynn, K., J. Daigle, J. Hoffman, F. Lake, N, Michelle, D. Ranco, C, Viles, G. Voggesser, P. Williams. 2013. The Impact of Climate Change on Tribal Traditional Foods. Climatic Change 120(3): 545- 556. DOI: 10.1007/978-3-319-05266-3_4

McClurken, J. 2009. Our People, Our Journey: The Little River Band of Ottawa Indians . East Lansing, MI: Michigan State University.

Michigan State University Extension. 2014. Michigan's Natural Communities. http://mnfi.anr.msu.edu/communities/index.cfm, Accessed September 2019.

Paerregaard, K. 2020. Communicating the Inevitable: Climate Awareness, Climate Discord, and Climate Research in Peru's Highland Communities. Environmental Communication 14(1): 112125.

Patty, L. 2001. Indian Nations of Wisconsin: Histories of Endurance and Renewal. Madison, WI: Wisconsin Historical Society.

Pierotti, R. 2011. Indigenous Knowledge, Ecology and Evolutionary Biology. New York, New York: Routledge. DOI 10.14237/ebl.2.2011.36

Munshi, D., P. Kurian, R. Cretney, S. Morrison, and L. Kathlene. 2020. Centering Culture in Public Engagement on Climate Change. Environmental Communication 14(5): 573-581. DOI: 10.1080/17524032.2020.1746680

Pilette, J. 2009. Little Traverse Bay Bands of Odawa Indians Native Plants Initiative. Little Traverse Bay Bands of Odawa Indians Environmental Services Department for Conservation Resource Alliance. 
Sleeping Bear Dunes National Lakeshore 2015. Natural Resources.

https://www.nps.gov/slbe/learn/nature/nrresearchplants.htm. Accessed September 2019.

Stoffle, R., R. Arnold, and A. Bulletts. 2016. Talking With Nature: Southern Paiute Epistemology and the Double Hermeneutic With a Living Planet. In Collaborative Heritage Management. By G. Tully and M. Rodges (eds.). Pp. 75-99. New Jersey: Gorgias Press. DOI: 10.31826/9781463236892-005

Stoffle, R., R. Arnold, and K. Van Vlack. 2015. Facing the Unimaginable: Hopi and Southern Paiute Respond to Massive Risk Events. The Applied Anthropologist 35(1): 13-22.

Stoffle, R., K. Brooks, E. Pickering, C. Sittler, K. Van Vlack. 2015. Climate Change Impacts on Odawa Contemporary Use Plants and Culture at Sleeping Bear Dunes National Lake Shore. Tucson, AZ: University of Arizona.

Stoffle, R., C. Sittler, K. Van Vlack, E. Pickering, H. Lim. 2020. Living Universe or GeoFacts: Stone Arches in Utah National Parks: epistemological divides in heritage environmental communication. International Journal of Intangible Heritage 15: 16-27.

Stoffle, R., R. Toupal, and N. Zedeno. 2003. Landscape, Nature, and Culture: A Diachronic Model of Human-Nature Adaptations. In Nature Across Cultures: Views of Nature and the Environment in Non-Western Cultures, H. Selin (ed.). Pp. 97-114. Great Britain: Kluwer Academic Publishers. DOI: 10.1007/978-94-017-0149-5

Stoffle, R., N. Zedeno, F. Pittaluga, and G. Dewey-Hefley. 1998. Traditional Ojibway Resources in The Western Great Lakes. Report prepared for National Park Service. Tucson, AZ: Bureau of Applied Research in Anthropology, The University of Arizona.

Tanner, H. 1987. Atlas of Great Lakes Indian History. Norman, OK: University of Oklahoma Press.

Trosper, R. and J. Parotta. 2012. Introduction: The Growing Importance of Traditional ForestRelated Knowledge. In Traditional Forest-Related Knowledge. By J. Parrotta and R. Trosper (eds), 1-36. Dordrecht: Springer. DOI: 10.1007/978-94-007-2144-9_13

Trusler, S. and L. Johnson. 2008. "Berry Patch" As a Kind of Place-the Ethnoecology of Black Huckleberry in Northwestern Canada. Human Ecology 36: 553-568. DOI: 10.1007/s10745-0089176-3

Turner, N. 2016. "We give them seaweed": Social economic exchange and resilience in Northwestern North America. Indian Journal of Traditional Knowledge 15(1): 5-15.

Vennum, T. 1988. Wild Rice and the Ojibway People. St. Paul, MN: Minnesota Historical Society Press. DOI: 10.17077/0003-4827.9484 
Vogesser, G., K. Lynn, J. Daigle, F. Lake, D. Ranco. 2013. Cultural impacts to tribes from climate change influences on forests. Climatic Change 120(3): 615-626. DOI: 10.1007/978-3319-05266-3_9

Warren, W. 1984. History of the Ojibway People. St. Paul, MN: Minnesota Historical Society Press.

Wegner, T. 2011. Indian Dances and the Politics of Religious Freedom, 1870 -1930. Journal of the American Academy of Religion 79(4):850-878.

Wildcat, D. 2013. Introduction: Climate Change and Indigenous Peoples of the USA. Climatic Change 120 (3): 509-515. DOI: 10.1007/s10584-013-0849-6

Wheeler, H. et al. 2020. The need for transformative changes in the use of Indigenous Knowledge along with science for environmental decision making in the Arctic. People and Nature 2: 544-556.

Yarnell, R. 1964. Aboriginal Relationships Between Culture and Plant Life in the Upper Great Lakes Region. Anthropological Papers \#23. Ann Arbor, MI: University of Michigan. DOI: 10.1525/aa.1965.67.4.02a00490 